McCance, R. A. and Shipp, H. L. (1933). Spec. Rep. Ser. med. Res. Coun., Lond., no. 187.

McCance, R. A., Widdowson, E. M. and Shackleton, L. R. B. (1938). Spec. Rep. Ser. med. Res, Coun., Lond., no. 213.

MeIntire, J. M., Schweigert, B. S. and Elvehjem, C. A. (1943). J. Nutrit. 26, 621.

MeIntire, J. M., Schweigert, B. S., Henderson, L. M. and Elvehjem, C. A. (1943). J. Nutrit. 25, 143.

Masters, H. (1918). Biochem. J. 12, 231.

Morgan, A. F. and Kern, G. E. (1934). J. Nutrit. 7, 367.

Nagel, A. H. and Harris, R. S. (1943). J. Amer. diet. Ass. 19, 23.

Odham, H. G. (1941). J. Nutrit. 22, 197.

Olliver, M. (1941). Chem. and Ind. 60, 586.

Oser, B. L., Melnick, D. and Oser, M. (1943). Food Res. 8, 115.

Schultz, A. S., Atkin, L. and Frey, C. N. (1942). Cereal Chem. 19, 532.

Schweigert, B. S., Nielsen, E., MeIntire, J. M. and Elvehjem, C. A. (1943). J. Nutrit. 26, 65 .

Van Duyne, F. O., Chase, J. T. and Simpson, J. I. (1944). Food Res. 9, 164.

Viswanath, B., Row, T. L. and Ayyangar, P. A. R. (1914-16). Mem. Dep. Agric. India. Chem. 4, 149.

Wilson, E. C. G. (1942). N.Z. J. Sci. Tech. [B], 24, 35.

Ziegelmayer, W. (1931). Z. Ernähr, 1, 25.

\title{
Discussion
}

Dr. J. C. Thompson (Food Research Laboratory, Barkers (Contractors), Ltd., e/o Morris Motors, Ltd., Cowley, Oxford), opener: The problem of the loss of ascorbic acid in food is one which has aroused considerable interest in recent years, particularly with food prepared on a large scale as for industrial canteens and British Restaurants. This is because there are certain processes peculiar to large scale catering which can cause the loss of considerable amounts of ascorbic acid.

Although the emphasis is on ascorbic acid because more estimations of the ascorbic acid content of foods have been made and more is known of its properties, this is simply because it is the easiest of the readily lost vitamins to estimate. As it is one of the most readily destroyed, and as the properties which lead to its disappearance from food, i.e., by being soluble in water, by being heat labile and by destruction by alkalis, are equally shared by other vitamins, particularly vitamin $B_{1}$ and members of the vitamin $B_{2}$ complex, it is safe to assume that if the ascorbic acid content of vegetables is satisfactory, the content of the other vitamins is assured. There are of course obvious exceptions to this assumption, e.g., dried legumes are rich in vitamin $B_{1}$ but are devoid of ascorbic acid.

The methods of cooking vegetables so as to conserve the greatest amount of ascorbic acid have been widely advertised by the Ministry of Food. They may be summarized as follows. All vegetables should be prepared, cooked and served as quickly as possible and with the minimum physical destruction of the vegetables, e.g., cabbage should be coarsely shredded with a sharp knife and potatoes should not be mashed. Expensive cooking, that is cooking involving large material waste, such as the discarding of the outer green leaves of cabbage and the peel of potatoes, or high fuel consumption because of the huge quantities of water used, produces food of inferior nutritive quality.

There are two aspects of large scale cooking I would like to mention, the use of bicarbonate of soda in the cooking of greens and the storage of food in the hot plate.

voL. 4,1946 ] 
The effect of alkalis on the destruction of ascorbic acid in vegetables has probably been exaggerated somewhat in the past. While pure ascorbic acid is destroyed by heating in the presence of alkalis, the use of a normal quantity of bicarbonate, 1 dessertspoonful to a 40 gallon boiler, has little effect on the ascorbic acid content of cooked cabbage. Table 1 shows that because of reduction in cooking time, cabbage so

TABLE 1

Effect of Bicarbonate of Soda on the Ascorbio Acto Content of Cabbage

\begin{tabular}{|c|c|c|}
\hline \multirow[b]{2}{*}{ Treatment } & \multicolumn{2}{|c|}{ Ascorbic acid content per $100 \mathrm{~g}$. } \\
\hline & $\begin{array}{c}\text { Cooked with bicarbonate } \\
\text { mg. }\end{array}$ & $\begin{array}{c}\text { Cooked without bicarbonate } \\
\text { mg. }\end{array}$ \\
\hline $\begin{array}{l}\text { Freshly cooked .. } \\
\text { In hot plate, } 1 \text { hour } \\
2 \text { hours } \\
\mathbf{3}, "\end{array}$ & $\begin{array}{l}36 \cdot 0 \\
29 \cdot 3 \\
18 \cdot 6 \\
17 \cdot 0\end{array}$ & $\begin{array}{l}33 \cdot 3 \\
29 \cdot 3 \\
26 \cdot 6 \\
22 \cdot 2\end{array}$ \\
\hline
\end{tabular}

cooked may have a higher ascorbic acid content than cabbage cooked without bicarbonate. It would appear, however, that when stored in the hot plate, cabbage which has been cooked with bicarbonate loses its ascorbic acid faster than cabbage cooked without bicarbonate.

Similarly, Johnston, Schauer, Rapaport and Deuel (1943) have reported that the vitamin $B_{1}$ content of peas is higher when bicarbonate is used in the cooking than without, which they attribute to a reduction in cooking time. There is the danger, however, that the injudicious use of bicarbonate will do more harm than good, but moderate use is an advantage.

TABLE 2

Loss of Ascorbid Aoid in Vegetables Stored in the Hot Plate

\begin{tabular}{|c|c|c|}
\hline Vegetable & $\underset{\text { hours }}{\text { Time in hot plate }}$ & $\begin{array}{l}\text { Ascorbic acid } \\
\mathrm{mg} \text { - per } 100 \mathrm{~g} \text {. }\end{array}$ \\
\hline Potatoes, mashed .. & 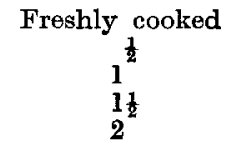 & $\begin{array}{l}6 \cdot 4 \\
3 \cdot 3 \\
2 \cdot 9 \\
2 \cdot 9 \\
2 \cdot 8\end{array}$ \\
\hline Cabbage $\quad \ldots \quad \ldots$ & $\begin{array}{c}\text { Freshly cooked } \\
\frac{1}{2} \\
1^{2} \\
1^{\frac{1}{2}} \\
2\end{array}$ & $\begin{array}{r}19 \cdot 0 \\
15 \cdot 8 \\
13 \cdot 9 \\
12 \cdot 7 \\
9 \cdot 5\end{array}$ \\
\hline
\end{tabular}

In the past it has been the practice in most canteens to have a preplated service, by which the servings on the individual plates often suffer a prolonged storage in the hot plate. This type of service is essential where speed is the prime concern, but the storage of meals in the hot plate besides causing a loss of aesthetic value leads to the destruction 
of considerable amounts of the ascorbic acid still remaining in the cooked vegetables. This is shown in Table 2.

The seriousness of these losses is illustrated in Table 3 showing the loss of ascorbic acid, by storage in a hot plate, from the vegetables of a meal consisting of $2 \mathrm{oz}$. of roast beef, $2 \mathrm{oz}$. Yorkshire pudding, $4 \mathrm{oz}$. cabbage, $8 \mathrm{oz}$. mashed potatoes, $4 \mathrm{oz}$. steamed pudding and $2 \mathrm{oz}$. custard.

TABLE 3

Loss of Ascorbic Acid from the Vegetables of a Meat during Storagf in a Hot Plate

\begin{tabular}{|c|c|c|c|c|}
\hline \multirow[b]{2}{*}{ Vegetable } & \multirow[b]{2}{*}{$\begin{array}{l}\text { Amount } \\
\text { oz. }\end{array}$} & \multicolumn{3}{|c|}{ Ascorbic acid content } \\
\hline & & $\begin{array}{l}\text { Initial } \\
\text { mg. }\end{array}$ & $\begin{array}{c}\text { After } \\
\frac{1}{2} \text { hr. storage } \\
\text { mg. }\end{array}$ & $\begin{array}{c}\text { After } \\
1 \text { hr. storage } \\
\text { mg. }\end{array}$ \\
\hline \multirow[t]{2}{*}{$\begin{array}{l}\text { Cabbage } \\
\text { Potatoes, mashed }\end{array}$} & $\begin{array}{l}4 \\
8\end{array}$ & $\begin{array}{l}21 \cdot 4 \\
14 \cdot 5\end{array}$ & $\begin{array}{r}17 \cdot 8 \\
7 \cdot 5\end{array}$ & $\begin{array}{r}14 \cdot 3 \\
5 \cdot 9\end{array}$ \\
\hline & Total .. & $35 \cdot 9$ & $25 \cdot 3$ & $20 \cdot 2$ \\
\hline
\end{tabular}

If $30 \mathrm{mg}$. be taken as a reasonable amount of ascorbic acid that a main midday meal should contain, then the above meal, which is a popular one in canteens, while supplying an adequate amount of ascorbic acid when freshly put on the plate, fails to do so after storage in the hot plate for even half an hour.

TABLE 4

Percentage Loss of Ascorbic Acid in Cooked Vegetables when Stored One Hovr in the Hot Plate Uncovered, Covered, and Uncovered with Hot Plate Saturated with Water Vapour

\begin{tabular}{|c|c|c|c|c|c|c|}
\hline \multirow{2}{*}{$\begin{array}{l}\text { Tempera- } \\
\text { ture } \\
{ }^{\circ} \mathrm{C} \text {. }\end{array}$} & \multicolumn{2}{|c|}{ Uncovered } & \multicolumn{2}{|c|}{ Covered } & \multicolumn{2}{|c|}{$\begin{array}{l}\text { Uneovered, } 100 \text { per } \\
\text { cent. humidity }\end{array}$} \\
\hline & Cabbage & $\begin{array}{l}\text { Potatoes, } \\
\text { boiled }\end{array}$ & Cabbage & $\begin{array}{l}\text { Potatoes, } \\
\text { boiled }\end{array}$ & Cabbage & $\begin{array}{c}\text { Potatoes, } \\
\text { boiled }\end{array}$ \\
\hline 100 & $45 \cdot 6$ & 28.9 & 27.4 & $22 \cdot 7$ & $69 \cdot 2$ & $29 \cdot 8$ \\
\hline 90 & 34.0 & $61 \cdot 1$ & $42 \cdot 2$ & $19 \cdot 8$ & $32 \cdot 6$ & 1.0 \\
\hline 80 & $30 \cdot 8$ & $27 \cdot 7$ & $60 \cdot 2$ & $17 \cdot 6$ & $46 \cdot 9$ & $\mathbf{1 3} \cdot 5$ \\
\hline 70 & $40 \cdot 3$ & $27 \cdot 6$ & $34 \cdot 0$ & $25 \cdot 9$ & 65.5 & $28 \cdot 6$ \\
\hline 60 & $33 \cdot 3$ & 1.2 & $26 \cdot 2$ & $15 \cdot 1$ & $64 \cdot 0$ & 23.0 \\
\hline 50 & $21 \cdot 8$ & $0 . \overline{9}$ & $23 \cdot \overline{0}$ & $3 \cdot 2$ & $42 \cdot 0$ & $44 \cdot 3$ \\
\hline 40 & $17 \cdot 4$ & 0.4 & 27.2 & $14 \cdot 1$ & - & - \\
\hline 30 & $12 \cdot 2$ & $4 \cdot \overline{1}$ & $26 \cdot 6$ & $18 \cdot 7$ & - & - \\
\hline 20 & $17 \cdot 5$ & 6.8 & 13.0 & $9 \cdot 6$ & - & - \\
\hline 2 & 0.7 & 5.0 & 21.9 & $3 \cdot 1$ & - & - \\
\hline
\end{tabular}

Hot plates, of course, are not all equally good. They vary in temperature, in the humidity of the contained air, and the extent to which they expose the food to air. Table 4 summarizes an investigation into the loss from cooked vegetables when stored in the hot plate under various conditions. From these results it may be deduced that the loss voL. 4, 1946] 
of ascorbic acid depends on the temperature of the hot plate and that a moist atmosphere, though without marked effect, tends to increase the rate of destruction. This may be due to the formation in a dry atmosphere of a skin on the vegetables which prevents access of air. At low temperatures the rate of ascorbic acid destruction is small, but as the lowest temperature at which food might be said to be hot is $60^{\circ} \mathrm{C}$., the hot plate must be maintained at a temperature not less than $60^{\circ} \mathrm{C}$. At this temperature storage for 1 hour results in the destruction of about one-third of the ascorbic acid.

It is evident therefore that, even under the best conditions, the hot plate is the cause of a very considerable loss of ascorbic acid and it is likely that it is equally the cause of a serious loss of vitamin $B_{1}$. Since palatability and attractiveness are important factors in ensuring both the consumption and digestibility of meals, "hot" meals must be served hot. Delay in serving meals should be eliminated, and vegetables in particular should be served, if possible, direct from "pot to plate". In industrial catering, a cafeteria service most closely approaches this ideal as it allows vegetables to be cooked at the latest possible time and in relatively small batches, each batch being so timed that it is served immediately it is cooked. Small batch cooking has additional advantages, since the available evidence shows that losses are lower in small than in large scale cooking.

The actual effect of the type of service on the ascorbic acid content of vegetables is illustrated in Table 5, which shows the results of surveys

TABLE 5

Comparison of the Mean Ascorbic acid Content of Cooked Vegetables as Served in Cantemes, (A) Cafeteria Service and (B) Preplated Service

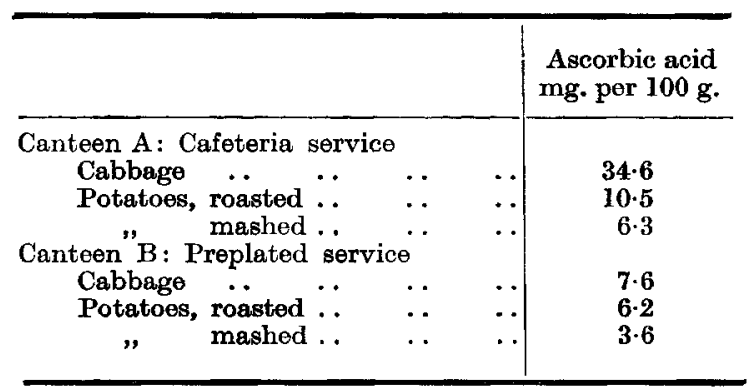

made in two canteens of similar size in the same town and during the same week. Canteen A had a cafeteria service and canteen B kept the meals hot on individual plates.

A cafeteria service not only ensures a high vitamin content of vegetables of a superior appearance and flavour; it allows to each individual customer a free choice of the kind and amount required.

REFERHNCE

Johnston, C. H., Schauer, L., Rapaport, S. and Deuel, H. J. (Jr.) (1943). J. Nutrit. 26, 227.

Speaker unknown: From a survey of 2000 families in Wales and in Yorkshire we found that 20 per cent. of all the vegetables which came into 
the house were wasted. This figure remained constant whether the housewife obtained the vegetables from a shop or from an allotment.

Mr. W. Holmes (Hannah Dairy Research Institute, Kirkhill, Ayr): Assuming a supply of fresh allotment vegetables, wilted vegetables from a town shop, and dehydrated vegetables, which would Miss Andross recommend?

Miss $M$. Andross replied: I would recommend fresh vegetables because I do not think the nutritive value of dried vegetables has been adequately investigated. They have not been tested with human beings. They may be a satisfactory substitute in emergency but cannot compete with fresh vegetables.

Miss H. J. S. Sandison (College of Domestic Science, 5 Atholl Crescent, Edinburgh): Generally there is very little plate waste with meat dishes but a large amount from green vegetables and salads. It was found that, when salads were served individually on plates along with meat, the tomatoes and meat were eaten and everything else was left. When salads were placed in separate dishes on the tables it was found that tomato and a little lettuce were taken. Last week, for example, in the case of 158 people who had salad, one-third of the lettuce, all the radishes and about two-thirds of the beetroot and carrot were wasted.

Miss M. Andross: I have a similar story to tell. In our canteen last summer we tried to introduce salad in the shape of sandwiches. The lettuce was left and the tomato eaten.

Dr. C. Douglas (Department of Health for Scotland, St. Andrew's House, Edinburgh): With regard to educating the young generation in the eating of salads, we find that we have no trouble whatever in war time nurseries. Our children will take raw beetroot grated, raw turnip and raw carrot without any trouble. At first among the 4-year-olds we had some rebels who tried to influence others, but these are now excluded from the room until the others have started to eat. Coloured plates are now used and a scarlet plate is very popular irrespective of what is put on it.

Dr. I. Leitch (Imperial Bureau of Animal Nutrition, Bucksburn, Aberdeen): With regard to this question of having to eat cabbage and how cabbage ought to be cooked, it seems a pity that we do not have more palatable green vegetables. The main problem is the supply of vitamin $\mathrm{C}$ in winter. For that the ideal solution is more fruit. Failing that we want more palatable vegetables, preferably fresh in winter. I do not think that dehydration provides the solution. The best answer is fruit, fresh or canned, including tomatoes. Fruits can be canned without much loss of nutritive value, some even gain in palatability. Dried potatoes from what I have heard have been a lamentable failure.

I should like to refer to one or two points from the papers. It has been argued that to conserve the salts from vegetables we should use the cooking water in soup. I was glad to hear Dr. Stewart say that the loss is insignificant in relation to the total intake, for the cooking water from vegetables, cabbage or turnip, for instance, does not, in my opinion, voL. 4, 1946] 
add to the palatability of soup. The next question is, does Dr. Stewart approve the recommendations of the Ministry of Food for cooking green vegetables in as little water as possible? He mentioned the question of the effect of cooking on the digestibility and nutritive value of proteins. The effect might be different with different foods since it is different with different feeding stuffs. It is necessary to heat cottonseed meal to render it non-toxic, but heating it to temperatures which make soya bean meal palatable and digestible greatly reduces the feeding value. I do not know whether any similar problem arises with regard to the proteins of human foods. On the question of the loss of vitamin $B_{1}$ in cooking, the main issue appears to be that, unless overmilled cereals and sugar are used, even with a 50 per cent. loss you would not reduce the proportion of vitamin $B_{1}$ to calories below the required level. It is the use of sugar and white bread that makes it necessary to take account of destruction of vitamin $B_{1}$.

Dr. C. P. Stewart replied: If cabbage is to provide an important part of the vitamin $C$ supply it might be best to eat it, or part of it, raw. The losses in cooking are by oxidation and by leaching. The more quickly the cabbage is heated to boiling, i.e., the greater the volume of boiling water, the less will be the loss by oxidation but the greater the loss by leaching. The best results are got by a compromise. In my experience the maximum amount of vitamin $\mathrm{C}$ is conserved if the pan is just the size to take the vegetable packed and covered with water.

Whether vitamin $\mathrm{C}$ is got from cabbage or other cooked vegetables, or salads is largely a matter of taste. It is not difficult to get $50 \mathrm{mg}$. a day, but since the requirement is probably nearer $15 \mathrm{mg}$. and potatoes can supply 15 to $20 \mathrm{mg}$. even at the worst time of year, there seems to be no reason to force people to eat either cabbage or raw salads.

A great deal more work is required on the value and digestibility of different proteins and the effect of cooking. The losses of vitamin $B_{1}$ in cooking are of no significance so long as we do not return to 70 per cent. extraction bread.

\section{Losses of Nutrients in the Conservation of Farm Produce and of Animal Feeding Stuffs}

Professor S. J. Watson (Edinburgh and East of Scotland College of Agriculture, 10 George Square, Edinburgh)

The preservation of foodstuffs for the use of farm stock in winter is one of the most important aspects of agriculture. The crops grown for this purpose have to be stored on the farm and can be divided into three main classes. There are the crops which are grown primarily for their seeds, such as the cereals and pulses; then come the root crops and, perhaps the most important of all, the green crops such as grassland herbage.

The practice in this country has been for the farmer to store also the foodstuffs which are used for direct human consumption and on him fall all the risks of storage of such crops.

Despite the importance of storage processes to the agricultural industry 